\title{
Determination of the biologically active flavour substances thujone and camphor in foods and medicines containing sage (Salvia officinalis L.)
}

\author{
Stephan G Walch ${ }^{1,2}$, Thomas Kuballa ${ }^{3}$, Wolf Stühlinger ${ }^{1}$ and Dirk W Lachenmeier ${ }^{3^{*}}$
}

\begin{abstract}
Background: The sage plant Salvia officinalis $L$. is used as ingredient in foods and beverages as well as in herbal medicinal products. A major use is in the form of aqueous infusions as sage tea, which is legal to be sold as either food or medicine. Sage may contain two health relevant substances, thujone and camphor. The aim of this study was to develop and validate an analytical methodology to determine these active principles of sage and give a first overview of their concentrations in a wide variety of sage foods and medicines.

Results: A GC/MS procedure was applied for the analysis of $\alpha$ - and $\beta$-thujone and camphor with cyclodecanone as internal standard. The precision was between 0.8 and 12.6\%, linearity was obtained from $0.1-80 \mathrm{mg} / \mathrm{L}$. The recoveries of spiked samples were between 93.7 and 104.0\% (average 99.1\%). The time of infusion had a considerable influence on the content of analytes found in the teas. During the brewing time, thujone and camphor show an increase up to about 5 min, after which saturation is reached. No effect was found for preparation with or without a lid on the pot used for brewing the infusion. Compared to extracts with ethanol $(60 \% \mathrm{vol})$, which provide a maximum yield, an average of 30\% thujone are recovered in the aqueous tea preparations. The average thujone and camphor contents were $4.4 \mathrm{mg} / \mathrm{L}$ and $16.7 \mathrm{mg} / \mathrm{L}$ in food tea infusions and $11.3 \mathrm{mg} / \mathrm{L}$ and $25.4 \mathrm{mg} / \mathrm{L}$ in medicinal tea infusions.

Conclusions: The developed methodology allows the efficient determination of thujone and camphor in a wide variety of sage food and medicine matrices and can be applied to conduct surveys for exposure assessment. The current results suggest that on average between 3 and 6 cups of sage tea could be daily consumed without reaching toxicological thresholds.
\end{abstract}

\section{Background}

The sage plant Salvia officinalis L. is a common ingredient used to flavour certain foods and beverages, especially in the Mediterranean diet (e.g. saltimbocca, a dish made of veal topped with ham and sage leaves). Sage is also used as an herbal medicinal product sold in the form of plant materials for making herbal tea, or as liquid extract or tincture. Depending on the intended use, sage is therefore regulated either as food or as medicine. In a recent toxicological review on thujone, which is a neurotoxic constituent of the essential oil of sage,

\footnotetext{
* Correspondence: lachenmeier@web.de

${ }^{3}$ Chemisches und Veterinäruntersuchungsamt (CVUA) Karlsruhe,

Weissenburger Strasse 3, D-76187 Karlsruhe, Germany

Full list of author information is available at the end of the article
}

we noted that the food and medicine laws contain a discrepancy [1].

The European food law recently deregulated the use of thujone-containing plants in food, i.e. both the previous limit for foodstuffs containing preparations based on sage $(25 \mathrm{mg} / \mathrm{kg})$ and the general limit for foodstuffs $(0.5$ $\mathrm{mg} / \mathrm{kg}$ ) [2] were removed from the new flavouring regulation, and only Artemisia-containing beverages (i.e. mainly absinthe) remain regulated [3]. This means that Salvia officinalis and other thujone-containing flavouring plants (besides Artemisia in beverages) can now be used in foods without restrictions. Nevertheless, thujone as such (i.e. in chemically pure form) is not allowed to be added to foods; it may only be indirectly introduced into foods by use of thujone-containing plants [3]. 
While the restrictions for foods have been lowered, the opposite has occurred for herbal medicines. The European Medicines Agency (EMA) has recently implemented an acceptable daily intake (ADI) of $5.0 \mathrm{mg} / \mathrm{per}-$ son for a maximum duration of use of 2 weeks in their Salvia officinalis monograph [4]. In a recent public statement, the EMA has reacted to new scientific evidence and now calls a range of exposure between 3 and $7 \mathrm{mg} /$ day as acceptable without concern, while proposing a new ADI of $6 \mathrm{mg} /$ person [5].

These regulatory differences lead to the strange situation wherein basically the same product (sage tea) may be marketed as food without any restriction, while its marketing as medicine in drug stores and pharmacies is regulated and certain warning labels are even required, such as "sage preparations should not be taken for more than 2 weeks" or "may impair ability to drive and use machines". In addition, its use by children and adolescents under 18 years of age is not recommended [4].

There is currently a scarcity of literature data regarding the thujone content of sage products on the market. For sage tea, our detailed literature review [1] detected only one report based on actual analytical data of a sage tea, which contained $2.0 \mu \mathrm{g} / \mathrm{ml}$ of thujone $(2 \mathrm{~g}$ of dried plant material in $150 \mathrm{ml}$ boiling water, steeped for 5 $\mathrm{min}$ ), corresponding to $0.3 \mathrm{mg}$ per cup [6]. Only $2.99 \%$ of essential oils were extracted during the preparation of such a tea [7]. The EMA [4] provided model calculations based on analytical data on essential oil yield and essential oil composition of Salvia officinalis folium using results from the study conducted by Länger et al. [8]. For an amount of $1 \mathrm{~g}$ sage leaves per 150-ml cup of hot water, the EMA assumed a thujone content ranging between $0.7 \mathrm{mg}$ and $5.0 \mathrm{mg}$ per cup, based on $3 \%$ essential oil containing $10-60 \% \alpha$-thujone and $4-36 \% \beta$-thujone and $17.6 \%$ extraction during tea steeping. This model calculation therefore led to a higher thujone content in a cup of sage tea than in the analytical data. We previously warned against model calculations based on essential oil analyses in the context of thujone estimation in absinthe [9]. Similar to wormwood, the thujone content in sage is highly variable. Typically, three chemotypes with low (9\%), medium (22-28\%), and high (3944\%) thujone contents are differentiated [10]. Thujone content also depends on drying conditions [11], harvest time and seasonal variation $[10,12,13]$, geographic and climatic conditions $[14,15]$ and fertilization [16], and it shows a gradient even inside a single individuum [17]. Sample preparation using steam distillation or solvent extraction may also have an influence [8]. The relative amount of essential oil constituents may also change during aqueous extraction due to the different solubilities: e.g. Lima et al. [7] reported $17.4 \% \alpha$-thujone in the essential oil, but $34.0 \%$ was contained in the essential oil fraction extracted from sage tea. While methods for the reduction of thujone in pharmaceutical preparations appear to be available [18], this practice may be in violation of the ISO 9909 standard, which specifies a range of $18.0-43.0 \%$ of $\alpha$-thujone and $3.0-8.5 \%$ of $\beta$-thujone [19]. The European Pharmacopoeia also requires that sage leaf oil is "rich" in thujone, however without specifying a range [20].

For these reasons, we think that only actual analytical data are sufficient for risk assessment of thujone in sage products. To fill this void in the literature, this study provides an analytical methodology based on our previously validated GC/MS procedure for analysing thujone in alcoholic beverages [21]. We also included camphor in the quantitative analysis, as this substance may also be health-relevant according to EMA [4]. The procedure was then applied to analyse a large sample collective $(n=86)$ of sage foods and medicines.

\section{Experimental}

\section{Samples and sample preparation}

Sage-containing foods and medicines were purchased between March and July 2010 in wholesale and retail supermarkets, drug stores, health food shops and pharmacies. We aimed to gather all available products and brands and therefore backordered further items at a pharmaceutical wholesale outlet. For several items, we ordered more than one package in order to gather data on charge variations. The sampling can be seen as representative for the current trade with sage products on the German market.

For sage tea, infusions were generally prepared according to the standard protocol specified in DIN 10809/ISO 3103 [22]. A $150-\mathrm{mL}$ white porcelain pot with lid was used. Deviating from the standard protocol, (which is for Camellia sinensis based tea), we used $1.5 \mathrm{~g}$ of herbal tea material (or 1 tea bag) instead of $2.0 \mathrm{~g}$ per cup, as this more realistically conforms to the specification as prescribed by the manufacturer on the labelling. In general, the tea material was infused in $150 \mathrm{~mL}$ of hot water for $15 \mathrm{~min}$. For comparison purposes, the same infusion was made using ethanol $(60 \% \mathrm{vol})$ instead of water. To further study the influences of tea preparation, one of the samples was extracted using different alcoholic strengths $(0,25,60,75$ and $99 \%$ vol $)$ at two different temperatures $\left(20^{\circ} \mathrm{C}\right.$ and $\left.80^{\circ} \mathrm{C}\right)$. The aqueous and alcoholic infusions were then directly used for extraction. Because the act of the tea preparation might also have an influence, 10 different teas were prepared with the lid of the pot either opened or closed. As a final experiment, the thujone extraction was studied during infusion in two brands by multiple samplings during 0 to 15 min infusion time. 
For liquid products (medicinal sage extracts and tinctures), the product was diluted into the required concentration with ethanol (60\% vol), typically $1: 50$ or 1:100. Solid products (sage sweets/candy) were homogenized in a laboratory mill and $10 \mathrm{~g}$ were dissolved in ethanol (60\% vol) under ultrasonication and mild warming. Fresh and dried sage plants (sold as spice) were prepared by homogenization of $30 \mathrm{~g}$ of plant material in $250 \mathrm{~mL}$ of ethanol $(60 \% \mathrm{vol})$. The resulting solution was filtrated and diluted into the required concentration (typically 1:50). All products were analyzed as is without physical alteration, i.e. in the form to be used by consumers. No drying steps (e.g. for the fresh products) were conducted and all results refer to fresh weight.

The extraction of the prepared solutions (i.e. the aqueous tea infusion as well as the homogenized or diluted solutions in the case of other products) was accomplished using a previously described procedure for the determination of thujone in alcoholic beverages [21], which was extended for the analysis of camphor. The procedure was based on the liquid-liquid-extraction with 1,1,2-trichloro-1,2,2-trifluoroethane first proposed by Rapp et al. [23]. After the addition of $350 \mu \mathrm{L}$ of cyclodecanone as internal standard (freshly prepared methanolic solution, $20 \mu \mathrm{g} / \mathrm{mL}), 1 \mathrm{~mL}$ of the sample was shaken with $10 \mathrm{~mL}$ of ethanol (15\% vol) and $1 \mathrm{~mL}$ of 1,1,2-trichloro-1,2,2-trifluoroethane for $60 \mathrm{~s}$ and centrifuged at $3.000 \mathrm{rpm}$ for $5 \mathrm{~min}$ for phase separation. The lower organic phase was drawn off using a transferpettor and filled in a GC vial. For calibration, thujone and camphor solutions $(0.1-80 \mathrm{mg} / \mathrm{L})$ were freshly prepared in ethanol $(15 \% \mathrm{vol})$ and extracted as the samples. The organic extracts were stored at $4^{\circ} \mathrm{C}$ until analysis.

\section{GC-MS measurement of thujone and camphor}

The GC-MS system used for analysis was an Agilent model 6890 Series Plus gas chromatograph in combination with a CTC Combi PAL autosampler and an Agilent 5973N mass selective detector. Data acquisition and analysis were performed using standard software supplied by the manufacturer. Substances were separated on a fused silica capillary column (HP-Innowax, $60 \mathrm{~m} \times$ $0.25 \mathrm{~mm}$ I.D., film thickness $0.25 \mu \mathrm{m})$. Temperature program: $45^{\circ} \mathrm{C}$ hold for $1 \mathrm{~min}, 5^{\circ} \mathrm{C} / \mathrm{min}$ up to $180^{\circ} \mathrm{C}, 25^{\circ}$ $\mathrm{C} / \mathrm{min}$ up to $240^{\circ} \mathrm{C}$, hold for $5 \mathrm{~min}$. The temperatures for the injection port, ion source, quadrupole and interface were set at $240^{\circ} \mathrm{C}, 230^{\circ} \mathrm{C}, 150^{\circ} \mathrm{C}$, and $250^{\circ} \mathrm{C}$, respectively. Split/splitless injection port $(1 \mu \mathrm{L}$, splitless $)$ and helium with a flow rate of $1.0 \mathrm{~mL} / \mathrm{min}$ as carrier gas were used.

To determine the retention times and characteristic mass fragments, electron impact (EI) mass spectra of the analytes were recorded by total ion monitoring. The analytes $\alpha$-thujone, $\beta$-thujone, and camphor, as well as the internal standard cyclodecanone were baseline separated. The retention times were $20.75 \mathrm{~min}$ for camphor, $18.29 \mathrm{~min}$ for $\alpha$-thujone, $18.78 \mathrm{~min}$ for $\beta$-thujone, and $26.36 \mathrm{~min}$ for cyclodecanone. For quantitative analysis, the chosen diagnostic mass fragments were monitored in the selected ion monitoring (SIM) mode. Camphor: $m / z 108$ as target ion and $m / z 109,152$ as qualifier ions; $\alpha$-/ $\beta$-thujone: $m / z 110$ as target ion and $m / z 81$ and 152 as qualifier ions; cyclodecanone: $m / z 111$ as target ion and $m / z 98$ and 154 as qualifier ions. For quantification, peak area ratios of the analytes to the internal standard were calculated as a function of the concentration of the substances. The limit of detection was $0.08 \mathrm{mg} / \mathrm{L}$ [21] for thujone and $0.02 \mathrm{mg} / \mathrm{L}$ for camphor. For further validation of the method, quality control samples were prepared and analysed using the procedure described above. Precision and recovery were determined with and without sample preparation. The data with sample preparation were gathered by analysing several different packages of the same batch.

\section{Total polyphenolic content expressed as Folin-Ciocalteu Index}

All phenolic compounds contained in the sample were oxidized by Folin-Ciocalteu (FC) reagent. This reagent is formed from a mixture of phosphotungstic acid, $\mathrm{H}_{3} \mathrm{PW}_{12} \mathrm{O}_{40}$, and phosphomolybdic acid, $\mathrm{H}_{3} \mathrm{PMo}_{12} \mathrm{O}_{40}$, which, after oxidation of the phenols, is reduced to a mixture of blue oxides of tungsten, $\mathrm{W}_{8} \mathrm{O}_{23}$, and molybdenum, $\mathrm{Mo}_{8} \mathrm{O}_{23}$. The blue colouration produced has a maximum absorption in the region of $750 \mathrm{~nm}$ and is proportional to the total quantity of phenolic compounds originally present. The FC-Index was determined according to the reference procedure for wine analysis [24] using a commercial FC reagent (Merck, Darmstadt, Germany, No. 1.09001.0100). To prepare the samples, $200 \mu \mathrm{L}$ of sage tea (from the infusion described above), $10 \mathrm{~mL}$ of distilled water, $1 \mathrm{~mL}$ of FC reagent, and $4 \mathrm{ml}$ of sodium carbonate solution $(20 \%, \mathrm{~m} / \mathrm{v})$ were placed into a calibrated $20 \mathrm{~mL}$ flask and filled up to the mark with distilled water. After a period of $30 \mathrm{~min}$ required for stabilization of the blue colour formed, the absorbance at $750 \mathrm{~nm}$ was measured. The result is expressed in the form of an index obtained by multiplying the absorbance by 20 .

\section{Results and Discussion}

\section{Method development and validation}

We were able to transfer our previous procedure intended for alcoholic beverages to sage foods and medicines. Sage teas could be treated in a similar manner as alcoholic beverages. Sage tinctures and extracts sold as medicines only needed to be diluted into the calibration range. Only for solid foods was a further preparation 
step necessary to get the terpenes ( $\alpha$ - and $\beta$-thujone, camphor) into solution, to be used for liquid-liquidextraction. Furthermore, we wanted to evaluate the extraction yield from the plant material during sage tea preparation, and we therefore conducted an extraction experiment, with results shown in Figure 1. Up to 60\% vol of alcohol, the extraction yield is considerably increased, while it remains constant if the alcoholic strength is further increased. The purely aqueous extraction $(0 \% \mathrm{vol}$ alcohol) yielded approximately $25 \%$ of the maximum yield. The extraction also depends on the temperature. Camphor shows the same extraction behaviour as thujone (data not shown). Because of these results, we extracted solid foods using $60 \%$ vol ethanol and made all dilutions using this alcoholic strength. Our result also confirms the observation in alcoholic beverages (absinthe) that the optimal strength is above 60\% vol, while at lower strength the essential oils precipitate (which is sometimes desired in certain drinking rituals) [25].

For sage food and medicines, an extractive sample preparation appeared to be obligatory, as the initial extracts are heavily coloured and would lead to matrix interferences as well as contamination of the GC inlet liner and MS ion source. Similar to our previous procedure, we therefore used a liquid-liquid extraction, which is comparably fast and easy to conduct. 1,1,2-Trichloro1,2,2-trifluoroethane has the highest extraction efficiency of flavour compounds from alcoholic solutions (see e.g.

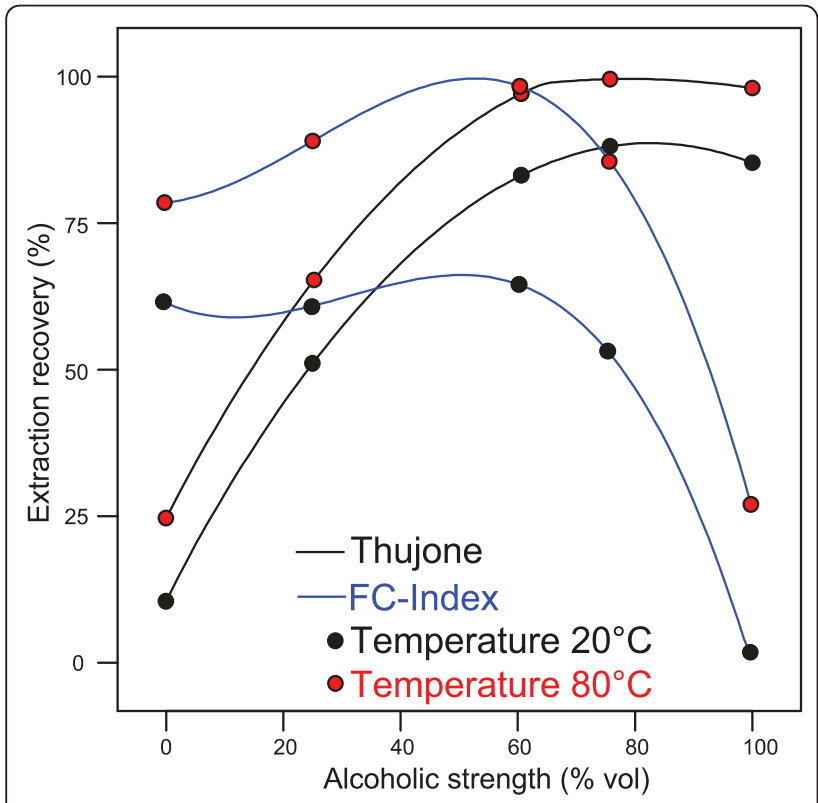

Figure 1 Extraction recovery of thujone and FC-Index using different alcoholic strengths at different temperatures (camphor exhibited exactly the same behaviour as thujone data not shown).
$[21,23,26,27])$. The advantage is that a complete extraction is reached in only one step, and we further controlled the extraction efficiency by applying an internal standard before the extraction and conducting extraction of all calibration samples. All analytes and the internal standard were baseline separated. A typical chromatogram is shown in Figure 2. The validation results are presented in Table 1 . The calibration curves were constructed from peak areas using the SIM mode, and they show a linear relationship for $\alpha$ - and $\beta$-thujone and camphor with coefficients of correlation of 0.999 . The linear range between 0.1 and $80 \mathrm{mg} / \mathrm{L}$ covers the thujone concentrations typically found in sage teas. Other products can be measured by dilution into this range. To improve quantitative analysis of essential oil compounds, the use of an internal standard was suggested [28]. In our case, we applied cyclodecanone, which was proposed by Kröner et al. [29,30] for the determination of thujone in absinthe. As we add the internal standard in the first step of the sample preparation process, not only changes during chromatography but also during extraction (e.g. due to differences in ethanol content for the herbal medicines) are corrected. In general, excellent precision was achieved, with ranges between 0.2 to $0.7 \%$ (without sample preparation) and 0.8 to $12.6 \%$ (including sample preparation). The recoveries of spiked samples were between 93.7 and 104.0\% (average 99.1\%).

\section{Influence of preparation conditions on thujone contents in sage tea}

During the brewing time, the increase of thujone and camphor showed an almost linear behaviour up to about 5 min, after which saturation was reached (Figure 3). If risk assessments show that the exposure to thujone should be minimized, the consumer recommendation could be to reduce the infusion time, e.g. to about $3 \mathrm{~min}$ instead of $15 \mathrm{~min}$. The behaviour of the extraction of polyphenols (i.e. the FC-Index), however, was almost similar in this case to that of the terpenes. The disadvantage of a reduced infusion time is, therefore, that the polyphenols (which are often attributed for the beneficial effects of sage [6]) are similarly reduced. A dependency between thujone and polyphenols in tea was also confirmed in our survey (Table 2), which proves significant positive linear correlations between FC-Index and $\alpha$-thujone $(R=0.60, p<0.001)$ and $\beta$-thujone $(\mathrm{R}=0.67, \mathrm{p}<0.0001)$. However, this was not the case between FC-Index and camphor $(\mathrm{R}=0.16$, $\mathrm{p}=0.39$ ).

Interestingly, in the alcohol experiment (Figure 1), the extraction of the polyphenols did not exhibit the same behaviour as that of the terpenes. Approximately $80 \%$ of polyphenols are extracted without alcohol, 


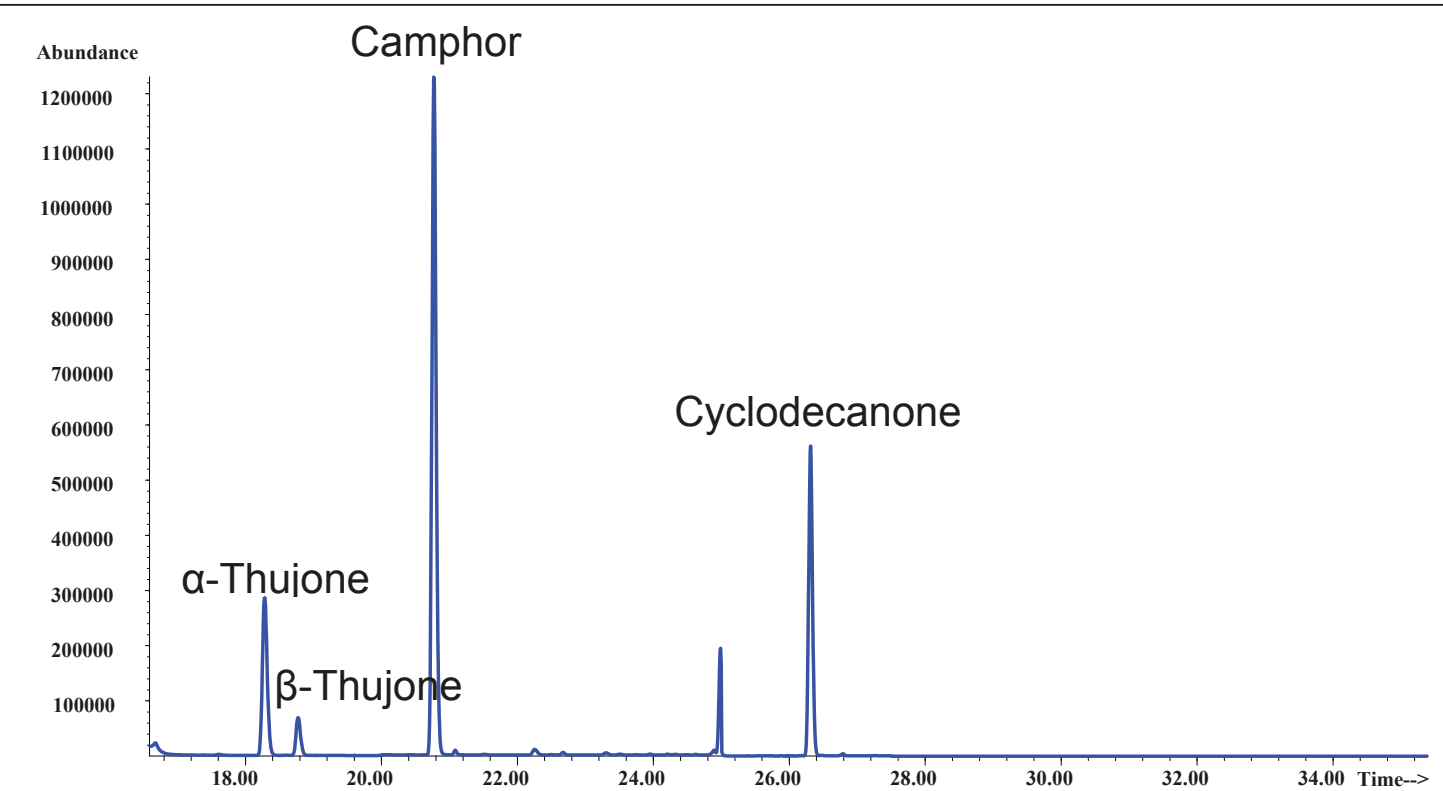

Figure $2 \mathrm{GC} / \mathrm{MS}$-SIM chromatogram of a sage tea containing $5.7 \mathrm{mg} / \mathrm{l}$ of $\alpha$-thujone, $1.3 \mathrm{mg} / \mathrm{l}$ of $\beta$-thujone and $18.7 \mathrm{mg} / \mathrm{l}$ of camphor.

whereas thujone is only at 25\% (Figure 1). The polyphenols are only slightly increased up to $60 \%$, and then decrease again. This is a first indication that the common aqueous preparation of a sage tea is preferable, as thujone is already avoided, while the polyphenols are still extracted at a very high degree. This was confirmed by our survey showing an average extraction of $30 \%$ thujone (range 14-48\%) in aqueous tea preparations compared to extraction with $60 \%$ ethanol (Table 2).

Finally, there were assumptions that the thujone content of sage tea could be higher if the tea was prepared using a lid on the pot. This could have two effects: (1) reduced evaporation and (2) increased extraction by reduced temperature decline over the infusion time. In our judgment, the first effect could be minor due to the comparably high boiling point of thujone (about $200^{\circ} \mathrm{C}$, see Ref. [31]). From our 10 samples, which we analysed both with and without lids, no clear trend was detectable. The half of the samples without lids had higher contents and the other half had lower contents. The average content with lid was $0.3 \mathrm{mg} / \mathrm{L}$ higher than without lid, which is not a significant difference considering the precision of the method (ANOVA $\mathrm{p}=$ 0.92). This clearly disproves the hypothesis of a considerable effect of using a lid: therefore, no consumer recommendation is needed regarding the brewing method.

\section{Occurrence of thujone and camphor in sage tea}

We analyzed 39 herbal teas, of which 8 brands were sold as food and 31 products were sold as medicines (14 different brands). In general, in both product groups a comparably wide variance of results was detected, which

Table 1 Validation results for determination of thujone in sage products

\begin{tabular}{|c|c|c|c|c|c|c|c|}
\hline \multirow[b]{2}{*}{ Sample } & \multicolumn{3}{|c|}{$\begin{array}{l}\text { Repeatability conditions without sample } \\
\text { preparation }(n=3)\end{array}$} & \multicolumn{3}{|c|}{$\begin{array}{l}\text { Repeatability conditions including sample preparation of } \\
\text { different packages }(n=9)\end{array}$} & \multirow[t]{2}{*}{ Recovery [\% } \\
\hline & $\begin{array}{l}\text { Mean } \\
(\mathrm{mg} / \mathrm{L})\end{array}$ & $\begin{array}{c}\mathrm{SD} \\
(\mathrm{mg} / \mathrm{L})\end{array}$ & $\begin{array}{l}\text { RSD } \\
{[\%]}\end{array}$ & $\begin{array}{l}\text { Mean } \\
(\mathrm{mg} / \mathrm{L})\end{array}$ & $\begin{array}{c}\mathrm{SD} \\
(\mathrm{mg} / \mathrm{L})\end{array}$ & $\begin{array}{l}\text { RSD } \\
{[\%]}\end{array}$ & \\
\hline Tea 1 & 11.43 & 0.03 & 0.2 & 11.43 & 0.49 & 4.3 & 97.4 \\
\hline Tea 2 & 12.78 & 0.06 & 0.5 & 12.78 & 0.68 & 5.3 & 104.0 \\
\hline Tea 3 & 14.66 & 0.08 & 0.5 & 14.66 & 0.65 & 4.4 & 92.8 \\
\hline Tea 4 & 4.27 & 0.03 & 0.7 & 4.27 & 0.54 & 12.6 & 101.4 \\
\hline Tea 5 & 16.12 & 0.05 & 0.3 & 16.12 & 1.63 & 10.1 & 93.7 \\
\hline Tea 6 & * & * & $*$ & 7.00 & 0.06 & 0.8 & $*$ \\
\hline Tea 7 & * & * & * & 18.00 & 0.78 & 4.3 & 102.5 \\
\hline Tea 8 & * & * & * & 17.42 & 0.39 & 2.2 & 102.0 \\
\hline
\end{tabular}

\footnotetext{
* not analyzed in this sample
} 

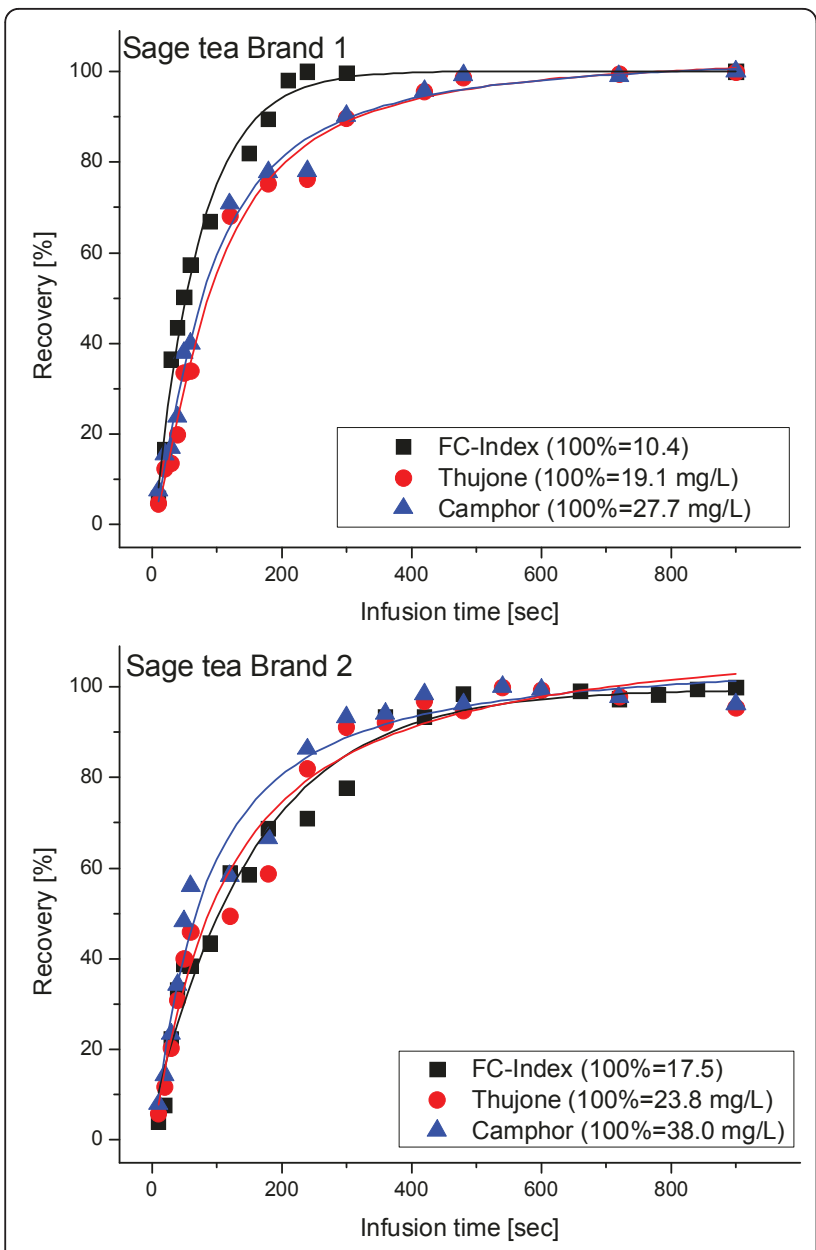

Figure 3 Dependence between infusion time and thujone, camphor and FC-index in two different sage tea brands.

confirmed the studies mentioned in the introduction [10-17]. This was further researched by looking at only one brand from which 18 different lots and product types (including tea bags) were analysed (Table 2). This confirms the high natural differences, as the total thujone contents in this single brand varied from $12.4 \mathrm{mg} /$ $\mathrm{L}$ to $30.1 \mathrm{mg} / \mathrm{L}$. The products sold as medicine had a tendency to higher thujone contents (sum of $\alpha$ - and $\beta$ thujone) from 0.2 to $30.1 \mathrm{mg} / \mathrm{L}$ (average $11.3 \mathrm{mg} / \mathrm{L}$ ), and camphor contents from 2.3 to $55 \mathrm{mg} / \mathrm{L}$ (average 25.4), while the ones sold as food contained 0.2 to 14.1 $\mathrm{mg} / \mathrm{L}$ thujone (average $4.4 \mathrm{mg} / \mathrm{L}$ ) and 1.5 to $43.8 \mathrm{mg} / \mathrm{L}$ camphor (average $16.7 \mathrm{mg} / \mathrm{L}$ ). The differences between foods and medicines are statistically significant on the $5 \%$ level for the thujones (ANOVA: $\alpha$-thujone $\mathrm{p}=$ 0.022 ; $\beta$-thujone $\mathrm{p}=0.012$ ) but not for camphor (ANOVA $\mathrm{p}=0.349$ ) and FC-Index (ANOVA $\mathrm{p}=0.409$ ). The statistical comparison is, of course, restricted by the low sample size: however, all products available on the German market at the time of sampling were included.
To finally confirm that there is in fact a difference between food and medicine products, a larger Europewide sampling needs to be conducted.

The explanation for the higher thujone contents in medicines than in foods could be twofold: on one hand, the European Pharmacopoeia [20] specifies minimum contents of essential oil for sage leaf drugs and also states the characteristic that "sage leaf oil is rich in thujone". A qualitative thin-layer chromatography test for thujone is also included in the identification assays specified in the Pharmacopoeia [20]. On the other hand, previous EU legislation [2] had specified a maximum thujone content of $25 \mathrm{mg} / \mathrm{kg}$ in food containing sage (in the final product ready for consumption). It can be speculated that food producers previously selected lowthujone varieties (i.e. the low-thujone chemotype), while medicine producers selected oil- and thujone-rich varieties (i.e. the medium and high chemotypes) to fulfil the Pharmacopoeia demands. As mentioned in the introduction, it must be stressed that in the newest amendment of the EU flavouring laws [3], the limit for sage products was omitted, so that currently no maximum limit for food applies anymore. This might lead to rising contents in the future, as no legislative pressure may exist anymore to select the low-thujone chemotypes, which may now be substituted by other selection criteria such as price and quality.

Regarding the exposure assessment from tea, the literature has described thujone contents of $0.3 \mathrm{mg}$ per cup [1], and EMA has estimated a thujone content of 0.7 to $5 \mathrm{mg}$ per cup from the data of Länger [7]. The analysed food teas $(\mathrm{n}=8)$ showed a thujone content ranging from 0.03 to $2.14 \mathrm{mg}$ per cup and a camphor content of 0.23 to $6.57 \mathrm{mg}$ per cup. The analysed medicinal teas $(\mathrm{n}=31)$ showed thujone contents ranging from 0.03 to $4.56 \mathrm{mg}$ thujone per cup and 0.35 to 8.25 mg camphor per cup. Although our results confirmed the range previously made in estimations by EMA, our data show that the maximum content of thujone per cup of tea is actually lower than assumed by EMA.

The situation for camphor is different. EMA estimated a camphor content of 0.53 to $2.3 \mathrm{mg}$ of camphor per cup. Our results show that the actual content is up to three times higher for products sold as food and up to four times higher for products sold as medicines.

\section{Occurrence of thujone and camphor in other sage products}

As expected, we found the highest contents of terpenes in the fresh sage samples $(\mathrm{n}=5)$, ranging from $223 \mathrm{mg} /$ $\mathrm{kg}$ to $1901 \mathrm{mg} / \mathrm{kg}$ for thujone and from 821 to 2610 $\mathrm{mg} / \mathrm{kg}$ for camphor. Dried sage leaves sold as food ingredients $(\mathrm{n}=3)$ showed a thujone content of 944 to $1353 \mathrm{mg} / \mathrm{kg}$ and a camphor content of 1651 to 4322 
Table 2 Results of sage tea (measured in the aqueous tea infusion prepared according to DIN 10809/ISO 3103:1980 in a cup without lid)

\begin{tabular}{|c|c|c|c|c|c|c|c|}
\hline Sample $^{a}$ & Sold as & $\begin{array}{l}\text { Number of } \\
\text { replicates }\end{array}$ & $\begin{array}{l}\alpha-\text { Thujone } \\
{[\mathrm{mg} / \mathrm{L}]}\end{array}$ & $\begin{array}{l}\beta \text {-Thujone } \\
{[\mathrm{mg} / \mathrm{L}]}\end{array}$ & $\begin{array}{l}\text { Camphor } \\
\text { [mg/L] }\end{array}$ & $\begin{array}{l}\% \text { yield of total thujone compared to } \\
\text { extraction with } 60 \% \text { vol ethanol }\end{array}$ & $\begin{array}{l}\text { FC- } \\
\text { Index }\end{array}$ \\
\hline Tea bag & Food & 2 & 0.7 & n.d. & 4.8 & $25 \%$ & 10.6 \\
\hline Herbal tea & Food & 2 & 8.2 & 1.3 & 43.8 & $27 \%$ & 9.6 \\
\hline Tea bag & Food & 2 & 0.2 & n.d. & 3.8 & $17 \%$ & 11.1 \\
\hline Tea bag & Food & 2 & 11.8 & 2.3 & 55.3 & $36 \%$ & 11.9 \\
\hline Herbal tea & Food & 2 & 5.8 & 1.3 & 18.7 & $22 \%$ & 9.6 \\
\hline Herbal tea & Food & 2 & 1.4 & 0.5 & 2.8 & $31 \%$ & 5.2 \\
\hline Herbal tea & Food & 2 & 1.1 & 0.5 & 2.3 & $36 \%$ & 6.5 \\
\hline Herbal tea & Food & 2 & 0.2 & n.d. & 2.4 & $15 \%$ & 14.0 \\
\hline - Average & Food & $n=8$ & 3.7 & 0.7 & 16.7 & $26 \%$ & 9.8 \\
\hline Tea bag & Medicine & 2 & 11.9 & 2.9 & 55.0 & $35 \%$ & 15.1 \\
\hline $\begin{array}{l}\text { Tea bag (sage } \\
\text { with honey) }\end{array}$ & Medicine & 2 & 0.2 & n.d. & 1.5 & $20 \%$ & 7.1 \\
\hline Tea bag & Medicine & 2 & 10.0 & 2.3 & 51.8 & $48 \%$ & 10.9 \\
\hline Herbal tea & Medicine & 3 & 8.8 & 2.7 & $*$ & $35 \%$ & 11.0 \\
\hline Herbal tea & Medicine & 3 & 11.6 & 3.3 & * & $21 \%$ & 16.7 \\
\hline Herbal tea & Medicine & 2 & 3.9 & 0.9 & * & $17 \%$ & 11.0 \\
\hline Herbal tea & Medicine & 3 & 12.6 & 2.9 & $*$ & $32 \%$ & 13.9 \\
\hline Herbal tea & Medicine & 1 & 19.0 & 4.4 & 36.0 & $32 \%$ & 14.6 \\
\hline Herbal tea & Medicine & 3 & 4.4 & 1.0 & 25.1 & $21 \%$ & 8.9 \\
\hline Herbal tea & Medicine & 4 & 8.5 & 1.5 & 13.0 & $20 \%$ & 6.4 \\
\hline Herbal tea & Medicine & 1 & 8.7 & 1.6 & 15.6 & $23 \%$ & 9.3 \\
\hline Herbal tea & Medicine & 1 & 5.7 & 1.3 & 18.2 & $31 \%$ & 8.5 \\
\hline Herbal tea & Medicine & 1 & 5.0 & 1.2 & 22.0 & $14 \%$ & 6.9 \\
\hline Herbal tea ${ }^{c}$ & Medicine & 2 & 11.5 & 3.0 & 21.5 & $38 \%$ & 14.2 \\
\hline Herbal tea ${ }^{c}$ & Medicine & 2 & 20.5 & 6.2 & 15.5 & $40 \%$ & 14.6 \\
\hline Herbal tea ${ }^{c}$ & Medicine & 1 & 19.1 & 5.6 & 14.8 & $40 \%$ & 15.4 \\
\hline Herbal tea ${ }^{c}$ & Medicine & 1 & 15.3 & 4.2 & 11.9 & $31 \%$ & 16.1 \\
\hline Tea bag ${ }^{c}$ & Medicine & 1 & 11.0 & 2.5 & 25.8 & $27 \%$ & 8.3 \\
\hline Herbal tea ${ }^{c}$ & Medicine & 1 & 21.5 & 5.3 & 15.4 & $32 \%$ & 15.0 \\
\hline Herbal tea ${ }^{c}$ & Medicine & 1 & 25.0 & 5.1 & 18.2 & $34 \%$ & 14.8 \\
\hline Herbal tea ${ }^{c}$ & Medicine & 1 & 22.2 & 4.6 & 13.6 & $40 \%$ & 14.3 \\
\hline Herbal tea ${ }^{c}$ & Medicine & 1 & 24.2 & 5.8 & 16.3 & $46 \%$ & 14.9 \\
\hline Herbal tea ${ }^{c}$ & Medicine & 1 & 24.8 & 5.0 & 15.9 & $42 \%$ & 11.5 \\
\hline Herbal tea ${ }^{c}$ & Medicine & 1 & 21.8 & 5.6 & 17.1 & $31 \%$ & 11.2 \\
\hline Herbal tea ${ }^{c}$ & Medicine & 1 & 24.0 & 5.0 & 16.1 & $42 \%$ & 11.6 \\
\hline Herbal tea ${ }^{c}$ & Medicine & 3 & 10.0 & 3.0 & * & $35 \%$ & 13.3 \\
\hline Herbal tea ${ }^{c}$ & Medicine & 3 & 13.8 & 5.2 & 14.6 & $23 \%$ & 15.0 \\
\hline Herbal tea ${ }^{c}$ & Medicine & 3 & 13.2 & 3.3 & 11.1 & $29 \%$ & 14.5 \\
\hline Herbal tea ${ }^{c}$ & Medicine & 3 & 14.9 & 3.1 & * & * & * \\
\hline Herbal tea ${ }^{c}$ & Medicine & 3 & 14.6 & 2.8 & * & * & * \\
\hline Herbal tea ${ }^{c}$ & Medicine & 3 & 10.7 & 1.7 & * & * & * \\
\hline - Average ${ }^{d}$ & Medicine & $\mathrm{n}=14$ & 9.1 & 2.2 & 25.4 & $27 \%$ & 13.6 \\
\hline
\end{tabular}

a Pure sage tea if not otherwise indicated

${ }^{\mathrm{b}}$ The indicated result is the average of all analyses of the same brand from different packages

' Products from the same manufacturer (different production lots)

${ }^{d}$ To avoid overproportial weight of the samples of the one manufacturer analysed several times (see footnote c), the overall average was calculated only between different manufacturers (average for each manufacturer)

* not analyzed in this sample 
$\mathrm{mg} / \mathrm{kg}$. Candies $(\mathrm{n}=4)$ contained 3.3 to $8 \mathrm{mg} / \mathrm{kg}$ thujone and 87.3 to $312 \mathrm{mg} / \mathrm{kg}$ camphor (Table 3).

Apart from the teas, we also analysed various medicines containing sage (Table 4). Overall they showed thujone content ranging from not detectable to $492 \mathrm{mg} /$ L. Interestingly, in the analysed sage juices $(\mathrm{n}=3)$, neither thujone nor camphor were detectable. Therefore, the question arises as to which part of Salvia was used in the preparation of these products, or if any part of it was used at all. In light of our extraction experiments and literature data [18], tinctures (or alcoholic extracts) expectedly showed thujone contents from 135 to 492 $\mathrm{mg} / \mathrm{L}$ and camphor contents of 203 to $883 \mathrm{mg} / \mathrm{L}$ higher than aqueous formulations.

Finally, we analysed semi-solid formulations for use in the mouth (such as teething gel or gum gel) $(n=4)$. The analysed thujone content ranged from 35.3 to 335 $\mathrm{mg} / \mathrm{kg}$. So-called herbal sedative tinctures had thujone contents ranging from not detectable to $18.3 \mathrm{mg} / \mathrm{kg}$. Notably, tablets (antispirant tablets, see Table 4) with the indicated traditional use to reduce sweating, showed the lowest thujone concentrations of 0.2 to $3.7 \mathrm{mg} / \mathrm{kg}$. We analysed 3 different brands (Table 4). Two brands (brand 1 and 2) contained dry extract of Salvia gained by aqueous extraction. We did not find detectable amounts of thujone or camphor in these preparations. The information provided by the manufacturer states that the tablets contain $80 \mathrm{mg}$ (brand 1) and $300 \mathrm{mg}$ (brand 2) of a dried extract of Salvia obtained by an aqueous extraction. Therefore, a low content of thujone can be expected. Brand 3 claims to use crushed dried sage leaves (200 mg per tablet). We analysed a thujone content of $3.7 \mathrm{mg} / \mathrm{kg}$. This means that every single tablet (weight: $0.45 \mathrm{~g}$ ) contains $0.0016 \mathrm{mg}$ of thujone. Calculating tablet and recommended daily dose $(3 \times 1-2$

Table 3 Results of sage foods (besides tea)

\begin{tabular}{|c|c|c|c|c|}
\hline Sample & $\begin{array}{l}\text { Analyzed } \\
\text { number of } \\
\text { packages a }\end{array}$ & $\begin{array}{l}\alpha \text {-thujone } \\
{[\mathrm{mg} / \mathrm{kg}]}\end{array}$ & $\begin{array}{l}\beta \text {-thujone } \\
{[\mathrm{mg} / \mathrm{kg}]}\end{array}$ & $\begin{array}{l}\text { Camphor } \\
{[\mathrm{mg} / \mathrm{kg}]}\end{array}$ \\
\hline Sage sweets/candy & 2 & 7.0 & 1.0 & 87.3 \\
\hline Sage sweets/candy & 2 & n.d. & 3.3 & 880 \\
\hline Sage sweets/candy & 2 & n.d. & n.d. & 86.4 \\
\hline Sage sweets/candy & 2 & n.d. & n.d. & 312 \\
\hline Fresh sage (Israel) ${ }^{\mathrm{b}}$ & 2 & 341 & 82 & 1456 \\
\hline Fresh sage (Israel) b & 2 & 818 & 298 & 821 \\
\hline Fresh sage (Israel) b & 2 & 1482 & 419 & 1695 \\
\hline Fresh sage (Israel) ${ }^{b}$ & 2 & 1110 & 323 & 1583 \\
\hline Fresh sage (Italy) ${ }^{b}$ & 2 & 173 & 56 & 830 \\
\hline Dried sage & 2 & 699 & 245 & 4322 \\
\hline Dried sage & 2 & 834 & 211 & 1651 \\
\hline Dried sage & 2 & 954 & 399 & 2610 \\
\hline
\end{tabular}

a The indicated result is the average of all analyses of the same brand

${ }^{b}$ The results for fresh products refer to fresh weight (no drying conducted)
Table 4 Results of sage medicines (besides tea)

\begin{tabular}{|c|c|c|c|c|c|}
\hline Sample & $\begin{array}{l}\text { Analyzed } \\
\text { number of } \\
\text { packages }\end{array}$ & $\begin{array}{l}\alpha- \\
\text { thujone } \\
{[\mathrm{mg} / \mathrm{kg}} \\
\text { or } \mathrm{mg} / \mathrm{L}]^{b}\end{array}$ & 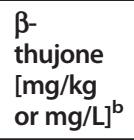 & 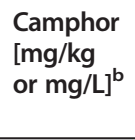 & $\begin{array}{l}\text { FC- } \\
\text { Index }\end{array}$ \\
\hline $\begin{array}{l}\text { Juice pressed } \\
\text { from fresh } \\
\text { sage leaves* }\end{array}$ & 3 & n.d. & n.d. & n.d. & 114.3 \\
\hline Sage juice* & 2 & n.d. & n.d. & n.d. & 135.8 \\
\hline $\begin{array}{l}\text { Sage leaves } \\
\text { extract* }\end{array}$ & 3 & 76.7 & n.d. & 164.7 & 138.1 \\
\hline $\begin{array}{l}\text { Tincture of } \\
\text { sage leaves* }\end{array}$ & 3 & 142.0 & 34.6 & 202.7 & 124.7 \\
\hline $\begin{array}{l}\text { Sage tincture } \\
\text { (drops)* }^{*}\end{array}$ & 3 & 135 & n.d. & 335.3 & 82.5 \\
\hline $\begin{array}{l}\text { Sage tincture } \\
\text { (drops)* }\end{array}$ & 3 & 361 & 68.3 & 883 & 107.4 \\
\hline Sage tincture* & 4 & 449 & 42.5 & 496 & 1.8 \\
\hline $\begin{array}{l}\text { Herbal tincture } \\
\text { (drops)* }^{*}\end{array}$ & 3 & 317 & 58 & 594 & 129.9 \\
\hline $\begin{array}{l}\text { Herbal tincture } \\
\text { (drops)* }^{*}\end{array}$ & 3 & n.d. & n.d. & 147 & 93.1 \\
\hline $\begin{array}{l}\text { Herbal tincture } \\
\text { (expectorant)* }\end{array}$ & 3 & n.d. & n.d. & n.d. & 10.1 \\
\hline Mouth rinse* & 2 & n.d. & n.d. & n.d. & 84.6 \\
\hline Teething gel & 3 & 260 & 75.2 & 455 & 1.8 \\
\hline Mouth gel & 3 & 22.9 & 12.4 & n.d. & 2.6 \\
\hline $\begin{array}{l}\text { Sage } \\
\text { containing } \\
\text { mouth spray* }\end{array}$ & 2 & 25.0 & n.d. & n.d. & 1.3 \\
\hline Mouth rinse* & 3 & 465 & 97.5 & 385 & 2.6 \\
\hline Gum gel & 3 & 46.9 & 20.3 & 10.7 & 0.8 \\
\hline $\begin{array}{l}\text { Mouth } \\
\text { ointment }\end{array}$ & 3 & 76.4 & 121 & 271 & 1.5 \\
\hline $\begin{array}{l}\text { Herbal anti- } \\
\text { dyspepsia } \\
\text { drops* }\end{array}$ & 3 & 8.5 & n.d. & n.d. & 0.6 \\
\hline $\begin{array}{l}\text { Herbal sedative } \\
\text { tincture* }\end{array}$ & 3 & n.d. & n.d. & n.d. & 754.0 \\
\hline $\begin{array}{l}\text { Herbal sedative } \\
\text { tincture* }\end{array}$ & 3 & 16.0 & 2.3 & n.d. & 1.2 \\
\hline $\begin{array}{l}\text { Cough drops } \\
\text { (containing } \\
\text { sage)* }^{*}\end{array}$ & 3 & n.d. & n.d. & n.d. & 27.5 \\
\hline Cough drops* & 3 & n.d. & n.d. & n.d. & 162.5 \\
\hline Breath drops* & 3 & n.d. & 0.2 & 0.2 & 52.4 \\
\hline $\begin{array}{l}\text { Antiperspirant } \\
\text { tablets (brand 1) }\end{array}$ & 3 & n.d. & n.d. & n.d. & 78.2 \\
\hline $\begin{array}{l}\text { Antiperspirant } \\
\text { tablets (brand 2) }\end{array}$ & 3 & n.d. & 0.8 & n.d. & 97.9 \\
\hline $\begin{array}{l}\text { Antiperspirant } \\
\text { tablets (brand 3) }\end{array}$ & 2 & 1.3 & 2.4 & 629 & 62.9 \\
\hline
\end{tabular}

a The indicated result is the average of all analyses of the same brand

${ }^{\mathrm{b}}$ Samples in liquid form calculated as $\mathrm{mg} / \mathrm{L}$ are marked with *

tablets) shows that with a daily dose of 6 tablets the consumer would take up $0.0096 \mathrm{mg}$ of thujone per day, which is considerably less than the exposure from tea. Of course, the question arises about the possible active 
compounds in such applications. In this case, the results of the FC-Index hint that other compounds are active substances in the formulation, probably the polyphenols, which are also extractable to some degree by water.

\section{Conclusions}

The legal status of thujone products when sold as food and when sold as medicines is considerably different. While standards for foods have been in existence for several decades, acceptable daily thujone intakes for medicines were only recently proposed by the EMA [4]. By using the data of the National Toxicology Program and a BMDL-ADI approach, Lachenmeier and Uebelacker [1] proposed a limit of $6.6 \mathrm{mg} /$ day. EMA reacted with a public statement reconsidering the published ADI and proposing a new ADI in a similar region of 6 $\mathrm{mg} /$ day [5]. This means that up to 6 cups of average food sage tea or up to 3 cups of average medicinal sage could be ingested daily without reaching this intake level. Therefore, we currently see no risk associated with the occasional food or medicinal use of sage (especially in the traditional use as herbal tea). The collection of data concerning sage preparations should be expanded in the future, preferably compounded by a quantitative risk-benefit analysis.

\section{Acknowledgements \\ Horst Mann and Hana Havel are thanked for exceptional commitment in operating and maintaining the GC/MS system. Hannelore Heger, Christina Diehl and Jeanne Mildenberger are thanked for their excellent technical assistance including sample preparation and analysis of FC index. No funding was specific to the production of this manuscript. The salaries for authors were provided by the affiliated organizations.}

\section{Author details \\ 'Department for Public Health and Health Technology Assessment, University for Health Sciences, Medical Informatics and Technology, Eduard Wallnöfer-Zentrum 1, A-6060 Hall in Tyrol, Austria. ${ }^{2}$ Zentrales Institut des Sanitätsdienstes der Bundeswehr Koblenz, Andernacher Strasse 100, D-56070 Koblenz, Germany. ${ }^{3}$ Chemisches und Veterinäruntersuchungsamt (CVUA) Karlsruhe, Weissenburger Strasse 3, D-76187 Karlsruhe, Germany.}

\section{Authors' contributions}

SGW contributed to the conceiving of the study, conducted the sampling and sample preparation, supervised the GC/MS measurements, and conducted the final data analysis including statistics and drafted the manuscript. DWL conceived of the study, coordinated the laboratory work, supervised the measurement of FC index and drafted the manuscript. TK developed the original GC/MS methodology and supervised the GC/MS measurements. TK and WS revised the paper draft. All authors read and approved the final manuscript.

\section{Competing interests}

The authors declare that they have no competing interests.

Received: 11 May 2011 Accepted: 21 July 2011 Published: 21 July 2011

\section{References}

1. Lachenmeier DW, Uebelacker M: Risk assessment of thujone in foods and medicines containing sage and wormwood - evidence for a need of regulatory changes? Regul Toxicol Pharmacol 2010, 58:437-443.
2. European Council: Council Directive (EEC) No 88/388 on the approximation of the laws of the Member States relating to flavourings for use in foodstuffs and to source materials for their production. Off $\rfloor$ Europ Comm 1988, L184:61-66.

3. European Parliament and Council: Regulation (EC) No 1334/2008 of the European Parliament and of the Council of 16 December 2008 on flavourings and certain food ingredients with flavouring properties for use in and on foods and amending Council Regulation (EEC) No 1601/ 91, Regulations (EC) No 2232/96 and (EC) No 110/2008 and Directive 2000/13/EC. Off J Europ Union 2008, L354:34-50.

4. EMA: Community herbal monograph on Salvia officinalis L., folium London, UK: European Medicines Agency; 2009.

5. EMA: Public statement on the use of herbal medicinal products containing thujone. EMA/HMPC/732886/2010 London, UK: European Medicines Agency; 2011.

6. Lima CF, Andrade PB, Seabra RM, Fernandes-Ferreira M, Pereira-Wilson C: The drinking of a Salvia officinalis infusion improves liver antioxidant status in mice and rats. J Ethnopharmacol 2005, 97:383-389.

7. Lima CF, Carvalho F, Fernandes E, Bastos ML, Santos-Gomes PC, FernandesFerreira M, Pereira-Wilson C: Evaluation of toxic/protective effects of the essential oil of Salvia officinalis on freshly isolated rat hepatocytes. Toxicol In Vitro 2004, 18:457-465.

8. Länger R, Mechtler C, Jurenitsch J: Composition of the essential oils of commercial samples of Salvia officinalis L. and S. fruticosa Miller: A comparison of oils obtained by extraction and steam distillation. Phytochem Anal 1996, 7:289-293.

9. Lachenmeier DW, Nathan-Maister D: Systematic misinformation about thujone in pre-ban absinthe. Deut Lebensm-Rundsch 2007, 103:255-262.

10. Perry NB, Anderson RE, Brennan NJ, Douglas MH, Heaney AJ, McGimpsey JA, Smallfield BM: Essential oils from Dalmatian sage (Salvia officinalis L.): Variations among individuals, plant parts, seasons, and sites. J Agric Food Chem 1999, 47:2048-2054.

11. Müller J, Köll-Weber M, Kraus W: Effect of drying on the essential oil of Salvia officinalis. Planta Med 1992, 58:A678.

12. Mirjalili MH, Salehi P, Sonboli A, Vala MM: Essential oil variation of Salvia officinalis aerial parts during its phenological cycle. Chem Nat Comp 2006 42:19-23.

13. Giannouli AL, Kintzios SE: Essential oils of Salvia spr: examples of intraspecific and seasonal variation. In SAGE - The Genus Salvia. Edited by: Kintzios SE. Amsterdam, The Netherlands: Overseas Publishers Association; 2000:69-79.

14. Máthé I Jr, Oláh L, Máthé A, Miklóssy W, Bernáth J, Blunden G, Patel AV, Máthé I: Changes in the essential oil production of Salvia officinalis under climatic conditions of the temperate belt. Planta Med 1992, 58 A680.

15. Lamien-Meda A, Schmiderer C, Lohwasser U, Börner A, Franz C, Novak J: Variability of the essential oil composition in the sage collection of the Genebank Gatersleben: a new viridiflorol chemotype. Flavour Fragr J 2010, 25:75-82

16. Geneva MP, Stancheva IV, Boychinova MM, Mincheva NH, Yonova PA: Effects of foliar fertilization and arbuscular mycorrhizal colonization on Salvia officinalis L. growth, antioxidant capacity, and essential oil composition. J Sci Food Agric 2010, 90:696-702.

17. Länger R, Mechtler C, Tanzler HO, Jurenitsch J: Differences of the composition of the essential oil within an individuum of Salvia officinalis. Planta Med 1993, 59:A635-A636.

18. Tegtmeier M, Harnischfeger G: Methods for the reduction of thujone content in pharmaceutical preparations of Artemisia, Salvia and Thuja. Eur J Pharm Biopharm 1994, 40:337-340.

19. Mockute D, Nivinskiene O, Bernotiene G, Butkiene R: The cis-thujone chemotype of Salvia officinalis L. essential oils. Chemija 2003, 14:216-219.

20. European Pharmacopoeia Commission: Sage leaf (Salvia officinalis). European Pharmacopoeia. 6 edition. Strasbourg, France: European Directorate for the Quality of Medicines; 2008, 2853.

21. Lachenmeier DW, Emmert J, Kuballa T, Sartor G: Thujone-Cause of absinthism? Forensic Sci Int 2006, 158:1-8.

22. ISO: ISO 3103. Tea - Preparation of liquor for use in sensory tests Geneva, Switzerland: International Organization for Standardization; 1980.

23. Rapp A, Hastrich H, Yavas I, Ullemeyer H: Zur einfachen, schnellen Anreicherung ("Kaltronmethode") und quantitativen Bestimmung von flüchtigen Inhaltsstoffen aus Spirituosen: Bestimmung von Thujon, 
Safrol, Isosafrol, $\beta$-Asaron, Pulegon und Cumarin. Branntweinwirtsch 1994, 134:286-289.

24. European Commission: Commission Regulation (EC) No 2676/90 determining Community methods for the analysis of wines. Off J Europ Comm 1990, L272:1-192.

25. Lachenmeier DW, Walch SG, Padosch SA, Kröner LU: Absinthe - A review. Crit Rev Food Sci Nutr 2006, 46:365-377.

26. Rapp A, Yavas I, Hastrich H: Easy and fast enrichment (Kaltron method) and quantitative determination of wine volatiles with capillary gas chromatography. Deut Lebensm-Rundsch 1994, 90:171-174.

27. Leitz J, Kuballa T, Rehm J, Lachenmeier DW: Chemical analysis and risk assessment of diethyl phthalate in alcoholic beverages with special regard to unrecorded alcohol. PLOS One 2009, 4:e8127.

28. Santos-Gomes PC, Fernandes-Ferreira M: Organ-and season-dependent variation in the essential oil composition of Salvia officinalis L. cultivated at two different sites. J Agric Food Chem 2001, 49:2908-2916.

29. Kröner LU, Padosch SA, Brückner MS, Lachenmeier DW, Mußhoff F, Madea B: Optimierung einer HS-SPME/GC/MS-Methode zur Bestimmung von a-/ $\beta$-Thujon in alkoholischen Getränken. Lebensmittelchem 2003, $57: 78$.

30. Kröner LU, Lachenmeier DW, Käferstein H, Rothschild M, Madea B, Padosch SA: Investigations on the medico-legal relevance of spirits containing thujone with special regard to toxicological-analytical aspects. Blutalkohol 2005, 42:263-271.

31. Lachenmeier DW: Thujone's properties. Chem Eng News 2008, 86(30):7-8.

doi:10.1186/1752-153X-5-44

Cite this article as: Walch et al:: Determination of the biologically active flavour substances thujone and camphor in foods and medicines containing sage (Salvia officinalis L.). Chemistry Central Journal 2011 5:44.

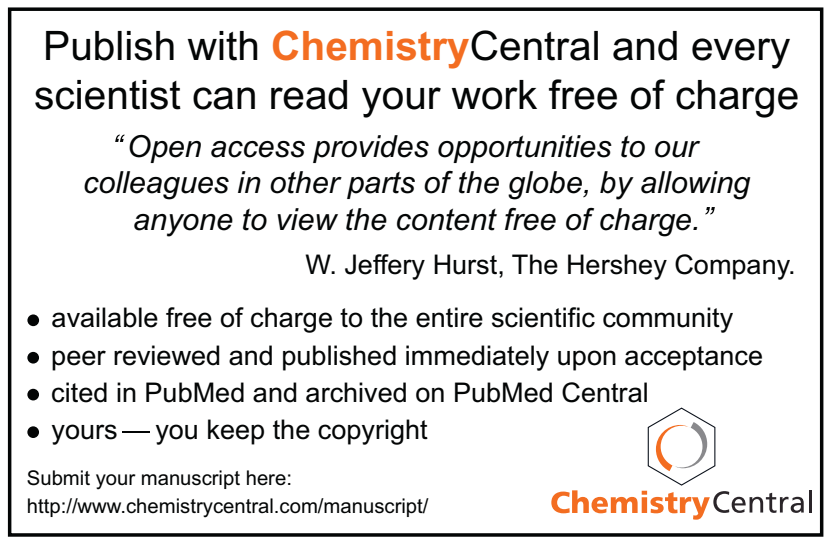

